\title{
Enterprise Maturity Model -The Technology Aligned Business Strategy Model for Indian Banks
}

\author{
Hemalatha Diwakar ${ }^{1}$ and Asish Saha ${ }^{2}$ \\ 1 SBI Chair Professor, National Institute of Bank Management, \\ Kondhwa, Pune 411048, diwakar@nibmindia.org, \\ www.nibmindia.org \\ 2 Director, National Institute of Bank Management, \\ Kondhwa, Pune 411048, director@nibmindia.org \\ www.nibmindia.org
}

\begin{abstract}
Public Sector Banks (PSB) in India are embarking on a comprehensive set of Information Technology initiatives. Since embracing technology alone is not enough to bring operational efficiency and profitability in the business it has become critical for PSBs to have an enterprise level strategy in which technology plans are in total alignment with business strategies. In this paper we propose an enterprise architecture which serves as a guideline for PSBs' IT strategies. This architecture is based on an assessment carried out on representative PSBs- studying their business \& Technology plans, business processes and information requirements with focus on some key areas like ALM, Credit Risk Management (CRM), Investment Portfolio Management (IPM), FOREX (Foreign Exchange) etc.

Based on the assessment and best IT enabled practices in the banking industry, an Enterprise Maturity Model (EMM) has been evolved to provide banks a structured frame-work having five hierarchical layers with defined business objectives at each level starting with basic objectives like increasing operational efficiency at the bottom most layer and leading up to very strategic objectives like maximizing wealth and stakeholder value at the highest level. To meet these objectives, a set of business systems for the key areas like ALM, CRM, IPM, Human Resource Management System and Customer Information Management System have been identified whose features are also layered with well-defined functionality to aid decision-making. The other critical component of the EMM is a multi-layered Information Technology architecture to support the applications at each layer. This methodology is unique and different from existing methodologies.
\end{abstract}

\section{Introduction}

To remain competitive and to provide modern facilities like ATMs, Telebanking, almost all Public Sector Banks (in which the government has major stake) in India are going for Information Technology based banking solutions. The Reserve Bank of India the Federal bank in India felt that since the new technology initiatives have an impact on business processes of the bank and the fact that it's critical for banks to derive business benefits from the technology investments, it is necessary to provide a set of guidelines to Indian banks for formulating their technology plans aligned to their business plans to meet business objectives. This paper describes the Enterprise Maturity Model that provides a framework for PSBs to integrate their technology

Please use the following format when citing this chapter:

Diwakar, H., Saha, A., 2006, in International Federation for Information Processing, Volume 205, Research and Practical Issucs of Enterprise Information Systems, eds. Tjoa, A.M., Xu, L., Chaudhry, S., (Boston:Springer), pp.231-240. 
plans with business objectives to attain total convergence of technology and business strategies in key areas of their business. The enterprise maturity model layered into five levels of maturity also addresses human resources and customers as they are an integral part of the system [1]. The paper is organized in the following way. The need for such a model is established and the methodology used in building the EMM is discussed. Next, Executive Information Systems needed for the key areas of banking, viz., Asset Liability Management, Credit \& Credit Risk Management, Investment Portfolio Management, Human Resources Information Management and Customer Relationship Management are identified and the layer wise application needs of each of the applications is presented. The final Enterprise Maturity Model along with the technology architecture is presented and the paper concludes with the expected benefits.

\section{Need for such a model}

The initiation of financial deregulation, globalization and open economy in late 90s has brought in the emergence of new market players in the Indian banking arena. These nimble competitors started banking in the country with technology driven banking solutions[2], brought in innovative style of banking with customers as their main focus, introduced multi-delivery channels to provide round the clock banking services and posed a big challenge to the Public Sector Banks PSB), which have been in banking business for more than half a century. It is worthwhile to note that the PSBs were using technology only for doing the branch centric operations, realized the need to opt for more technology based solutions to sustain business, retain customers and improve business prospects. Since then, the PSBs have started heavily investing in information technology.

Based on a detailed study of representative public sectors banks (visits, questionnaires, interviews) covering a detailed study of their business objectives, technology initiatives an analysis of the extent of correlation between the two initiatives (as technology is an enabler for attaining business success) revealed that: .

The banks are inducting technology at a great pace but only operational efficiency and correctness of data is being achieved in the process.

The banks need to work out more rigorously on how their technology will help them to achieve their long term business plans.

More serious need for considering the impact of technology induction on the current and future banking employees and skill sets needed for managing the banking business in the long run.

Hence it became evident that there is an immediate need to develop an enterprise level technology aligned business model, which the Indian banks can abide by. In this paper one such model called as Enterprise Maturity Model (EMM) that is suitable for the Indian banking environment is presented. 


\section{Procedure for building Enterprise Maturity Model}

A common set of business objectives listed below have been chosen as the drivers for business success: -

Size, Growth \& Mix of Business

Market Share

Sectoral allocation of Business

Geographical spread

Product/Price/Cost Leadership

Risk adjusted Performance measures

Profit optimization

Shareholder's wealth maximization and Brand Image

These business objectives translate into business strategies such as bringing down the NPAs, enlarging profitable customer base, good credit appraisal systems to safeguard the bank, profitable investment propositions etc which mandates an excellent Executive Information system for decision making. This EIS is an aggregation of sophisticated decision support systems in Asset Liability management (ALM), Credit \& Credit risk management (CRM), Investment Portfolio management (IPM) and Foreign Exchange Systems (FOREX), and not but the least, an extensive customer Information management system (CIM) and human resource management system (HRM). Each of these areas i.e., ALM, CRM, IPM, FOREX, CIM and HRM is conceptually well advanced, and hence heavily depend on technology support to reap the full benefits. For example, they need a comprehensive information base related to banking, customers, and other external sources, which are to be accessed bank wide (that needs a communication network) at any point in time. Also these systems use extensively, quantitative, statistical and simulation techniques, neural networks, time series analysis, to name a few.

It is to be noted that the banks cannot implement an integrated EIS instantly. Hence it is logical to look at the ALM, CRM, IPM etc., as incremental systems, comprising of multiple layers, to be developed in the bottom up way, so as to attain the final state of sophistication in the EIS. Every level, in each of the above-mentioned systems, have well defined purposes, add value in decision making and as they grow in levels the value added and the complexity involved in the systems are higher. Each level is abstracted out with well-defined functionality in mind. As all these individual systems are to work in an integrated fashion to provide an integrated, bank level EIS, it is important to normalize the corresponding levels of each of these systems to get a single level in the enterprise level application architecture. This exercise will help in defining the required technology architecture for each of the levels to accomplish its business purposes. This involves identifying the data needs, other technology-based needs such as network connectivity, centralized or decentralized approach for data store, periodicity for data exchange etc, and arrives at common technology requirements. This is the way, the enterprise level businesstechnology architecture or enterprise maturity model is worked out. 


\section{Key functional areas in the model}

\subsection{Asset Liability Management}

Asset Liability Management (ALM) aims at simultaneous planning of all assets and liability positions in the bank's balance sheet so that bank mitigates the risks arising out of changes in interest rates, providing adequate liquidity and enhancing the value of the bank [3]. From risk management perspective, ALM mainly handles Interest Rate Risk and Liquidity Risk in the banking book. ALM is the process of planning, organizing and controlling asset and liability mixes, volumes, yields and rates in order to achieve targeted interest margin [4]. The primary goal is to control interest income and expenses and to increase the net interest margin on a continuous basis. In order to establish efficient ALM systems banks require adequate, accurate data in timely manner which mostly originates at branch level such as Term Deposits, Term Loans, Non-maturity items in the balance sheet such as Savings Bank deposits, Cash credit, etc. . The model recommends a layered implementation of ALM functionality which is summarized in Table 1.

\subsection{Credit Risk Management}

Credit risk is one of the oldest risks that is faced by the banks world-wide. Since exposures to credit risk continues to be the leading driver of risk, it is necessary for banks to identify measure, monitor and control credit risk so that they can hold adequate capital against the same [5].In the past banks have faced serious risks due to lax in credit standards for counter parties and a lack of attentions to changes in economic and other external conditions [6,7]. To overcome these problems, it is essential for banks to make both qualitative and quantitative assessment of borrower's credit standing which will help them in estimating his/her repayment capacity. In Table 2, a layered Credit Risk Management Architecture is presented. 


\begin{tabular}{|c|c|c|}
\hline Layer Description & Data & Source \& Frequency \\
\hline $\begin{array}{l}\text { L1- Understand the Static Liquidity Position, } \\
\text { Interest Rate Sensitivity and Dynamic } \\
\text { Liquidity Position } \\
\text { Regulatory Reporting }\end{array}$ & $\begin{array}{l}\text { Transaction \& Account } \\
\text { Level Data } \\
\text { Time Series Data of } \\
\text { Aggregate Balances, } \\
\text { Point of time data }\end{array}$ & $\begin{array}{l}\text { Branch / Head office } \\
\text { (Fort nightly ) } \\
\text { HO / Regional offices / } \\
\text { Weekdy) } \\
\text { HO (Fortnight/Weekly) }\end{array}$ \\
\hline $\begin{array}{l}\text { L2- Assess the sensitivity of earnings numbers } \\
\text { to interest rate changes on assets and } \\
\text { liabilities } \\
\text { Setting-up and tolerance limits based on } \\
\text { gaps, cumulative gaps and sensitivity of } \\
\text { earnings (Earnings-at-Risk) }\end{array}$ & $\begin{array}{l}\text { Data in Layer-I } \\
\text { Time Series Data on } \\
\text { Interest Rates }\end{array}$ & $\begin{array}{l}\text { HO / External Data in } \\
\text { Public Domain } \\
\text { Frequency Quarterly }\end{array}$ \\
\hline $\begin{array}{l}\text { L3- Implementing the Economic Value } \\
\text { Approach of Interest Rate Risk } \\
\text { Management } \\
\text { Valuation of assets, liabilities and off- } \\
\text { balance sheet items } \\
\text { Implementation of Duration, Duration } \\
\text { Gap and Convexity Analysis }\end{array}$ & $\begin{array}{l}\text { Data in Layer - I, } \\
\text { Current Interest Rates on } \\
\text { Assets and Liabilities for } \\
\text { various tenors, } \\
\text { Spot and Forward Rates }\end{array}$ & $\begin{array}{l}\text { HO } \\
\text { Third Party Sources } \\
\text { Frequency Quarterly (Q) }\end{array}$ \\
\hline $\begin{array}{l}\text { L4- Stress testing of liquidity and parameters } \\
\text { rate sensitivity - both the earnings and } \\
\text { EVE }\end{array}$ & $\begin{array}{l}\text { Stress Events } \\
\text { Stress Scenarios }\end{array}$ & $\begin{array}{l}\text { Internal Data on Stressful } \\
\text { Events - HO } \\
\text { Generation of Stress } \\
\text { scenarios - HO (Q) }\end{array}$ \\
\hline $\begin{array}{ll}\text { L5- } & \text { Simulation of Gaps, Earnings, EVE, } \\
& \text { Durations and Duration Gap }\end{array}$ & $\begin{array}{l}\text { Input-output } \\
\text { Felationships established } \\
\text { over time }\end{array}$ & Quarterly \\
\hline L6- Implementation of Funds Transfer Pricing & $\begin{array}{l}\text { Data in Phase - I } \\
\text { Data on Interest Rates }\end{array}$ & Quarterly \\
\hline
\end{tabular}

Table1. ALM architecture

\subsection{Investment portfolio management}

Management of Investment Portfolio has become an important function in the recent past due to various reasons such as the high-profile trading disasters in the international markets, regulatory pressures to make capital requirements in tune with the risks arising out of changing market conditions, and heightened volatility of interest rates, etc. Uncertainties in the interest rate environment continue to pose immense challenge for the banks to manage risks in investment portfolio in a more efficient manner. This necessitates availability of an efficient information system that will facilitate evaluation of risk-return measures not only at the individual security level but also at the portfolio context [8]. Such system will help banks to achieve optimum total return on investment portfolio which is consistent with the risk tolerance limits placed for various sources of risks and other regulatory requirements. The layered architecture of Investment Portfolio Management is presented in Table 3. 


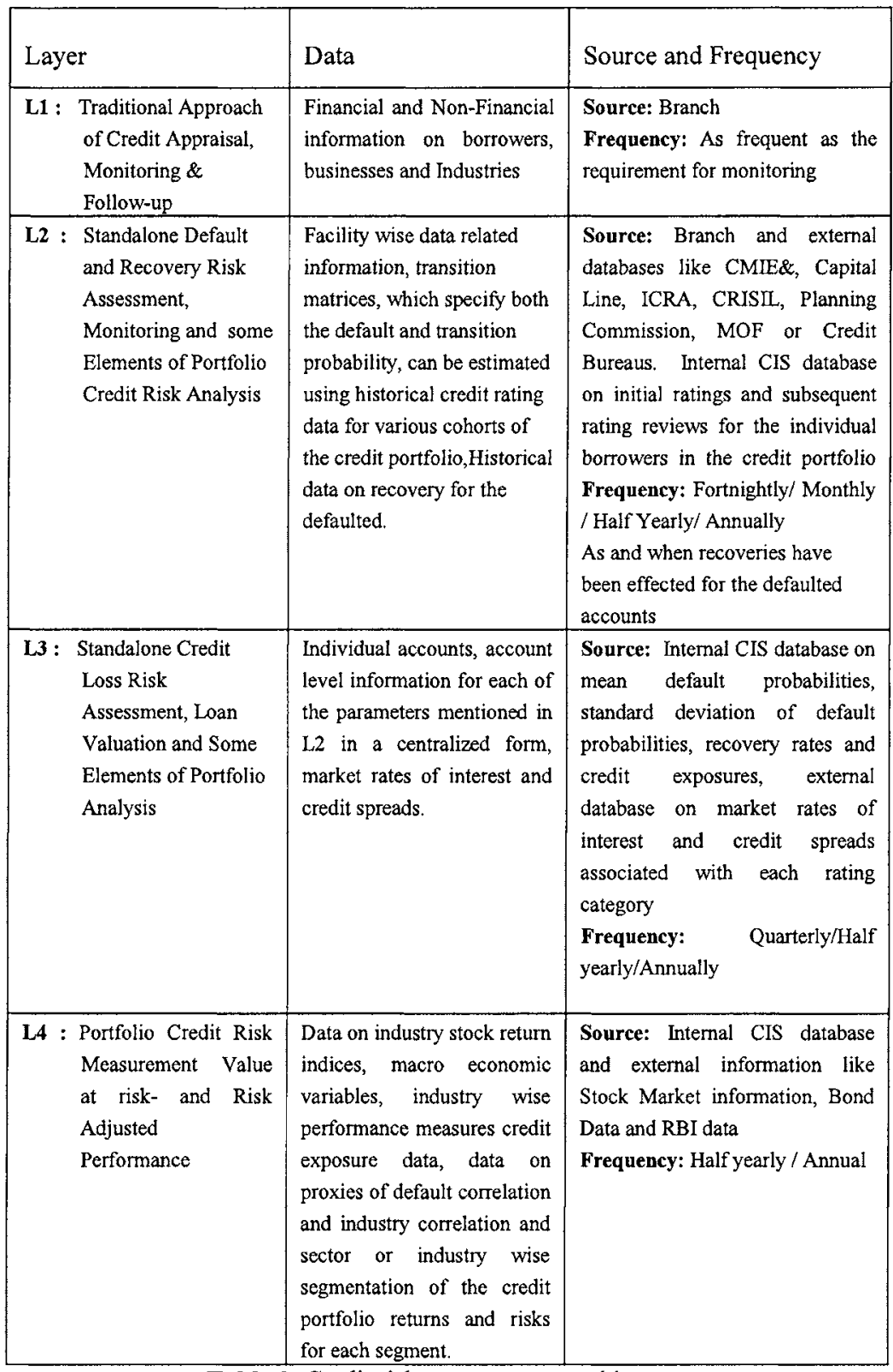

Table 2. Credit risk management architecture 


\begin{tabular}{|c|c|c|}
\hline $\begin{array}{l}\text { L1: Yield Measures such as Current Yield, } \\
\text { YTM and return measures at individual } \\
\text { security level and at portfolio level }\end{array}$ & $\begin{array}{l}\text { Individual Security - } \\
\text { wise Data }\end{array}$ & $\begin{array}{l}\text { HO } \\
\text { Frequency Daily }\end{array}$ \\
\hline $\begin{array}{l}\text { L2: Analysis of relative attractiveness of } \\
\text { securities to evaluate swap opportunities, } \\
\text { Yield Curve Creation and Valuation of } \\
\text { securities, Analysis of Market Risk using } \\
\text { factor sensitivity measures: Duration, } \\
\text { Modified Duration, PVBP and } \\
\text { Convexity }\end{array}$ & $\begin{array}{l}\text { Data in Layer - I } \\
\text { RBI - NDS data } \\
\text { NSE -WDM data } \\
\text { FIMMDA Data } \\
\text { Data on Credit Spreads }\end{array}$ & $\begin{array}{l}\text { External Sources } \\
\text { collected by HO } \\
\text { Investment dept } \\
\text { Frequency Daily }\end{array}$ \\
\hline $\begin{array}{l}\text { L3 - Implementing Volatility Based Measures } \\
\text { of Risk - Valuc-at-Risk (VAR) stress } \\
\text { testing and back-testing } \\
\text {-Liquidity Analysis for securities and } \\
\text { portfolio }\end{array}$ & $\begin{array}{l}\text { Data in Layer - I } \\
\text { Data on traded } \\
\text { securities in the market } \\
\text { Spot Rate Data - } \\
\text { Internally generated } \\
\text { and from external } \\
\text { sources }\end{array}$ & $\begin{array}{l}\text { HO } \\
\text { External sources } \\
\text { Frequency } \\
\text { Fortnightly }\end{array}$ \\
\hline $\begin{array}{l}\text { L4: } \text {-Analysis of Embedded Options in } \\
\text { securities } \\
\text {-Portfolio Optimization } \\
\text { Simulation }\end{array}$ & $\begin{array}{l}\text { Data in Layer - I } \\
\text { Internal and External } \\
\text { Constraints } \\
\text { Data on Yield curve } \\
\text { Behaviour }\end{array}$ & $\begin{array}{l}\text { HO } \\
\text { External Sources } \\
\text { Frequency Quarterly }\end{array}$ \\
\hline
\end{tabular}

Table 3. Investment Portfolio Management Architecture

\subsection{Human Resource Information Management and Customer Information Management System}

The introduction of technology, and the new challenges in the form of cut-throat business and challenges from the private and foreign banks calls for a change in the human resource talent management and leadership planning process. As the banks, like any corporate house, also need leaders, critical thinkers, and decisionmakers at all levels, it is need of the hour to have a Human resource information system, which can help the banks, not only for managing the human resources but also to assist in creating competencies, job profiles, help in career planning (for individuals) and succession planning for the top bracket jobs in the banks.. The various levels of need in the human resource side are also included in the enterprise maturity model.

In a similar way, as the banking scenario has shifted its marketing paradigm from product centric to customer centric, having a good customer information system (CIM) has become crucial for relationship building and business expansions. 


\section{Enterprise Level Maturity Model and Technology Requirements}

Three diagrams for EMM are presented; Individual systems normalised and synthesized, presented as Fig. 1. The common business objectives stated in the beginning are layered as per their realization in the EMM and a pyramidal representation of the same EMM levels is depicted in Fig. 2 and the final diagram for the technology requirements to accomplish the needs is mentioned in Fig. 3.

The individual ALM, CRM, IPM, CIM, HRM systems are normalized and the final synthesized enterprise level maturity model is presented in the diagram below.

\begin{tabular}{|l|l|l|l|l|l|}
\hline $\begin{array}{l}\text { Business } \\
\text { layers }\end{array}$ & ALM & IPM & CRM & HRM & CIM \\
\hline M5 & L6 EIS & L4 EIS & L4 EIS & L3 EIS & L4 EIS \\
\hline M4 & L5 DSS & L4 EIS & L3 DSS & L3 DSS & L3 DSS \\
\hline M3 & L4\&L3 DSS & L3 DSS & L.2 DSS & L2 DSS & L2 DSS \\
\hline M2 & L1\&L2 MIS & L.1\& L2 MIS & L1 MIS & L1 MIS & L1 MIS \\
\hline M1 & & & & & \\
\hline
\end{tabular}

Fig. 1. Normalized, synthesized individual functional area systems in EMM

IPM: L1, L2, L3, L4 refer to various Layers in Investments architecture table.

ALM: L1, L2, L3, L4, L5, L6 refer to various phases in ALM architecture table.

CRM: L1, L2, L3, L4 refer to various Layers in Credit Risk Management architecture table.

HRM: L1 - Employee Information system, L2 - Job Profiling, Competency Requirement, 360 degree assessment, Gap Identification, Redesigning Performance Appraisal System, L3 - Training and Development, Succession planning \& Career development

CIM): L1 - Unique Customer ID, Start Collecting Individual Customer Information, L2 - Customer Information is available at branch level, L3 - Analyzing Branch / Region / Zonal Customer Relationship data, L4 - Customer Segmentation \& Product positioning MIS: Management Information System, DSS: Decision Support System, EIS:

Executive Information System

\subsection{Technology Architecture}

The objectives to be attained, the kind of reports needed whether for information or for analysis or for forecasting, the frequency at which it should be generated, the data needed for it, where all they are available, multiple sites (branches) or at a centralized place, the source of data, all these factors determine the kind of 
technology support needed at each of the EMM layers as given in EMM Fig. 1. The technology requirements are presented in a pyramidal form in EMM Fig. 3.

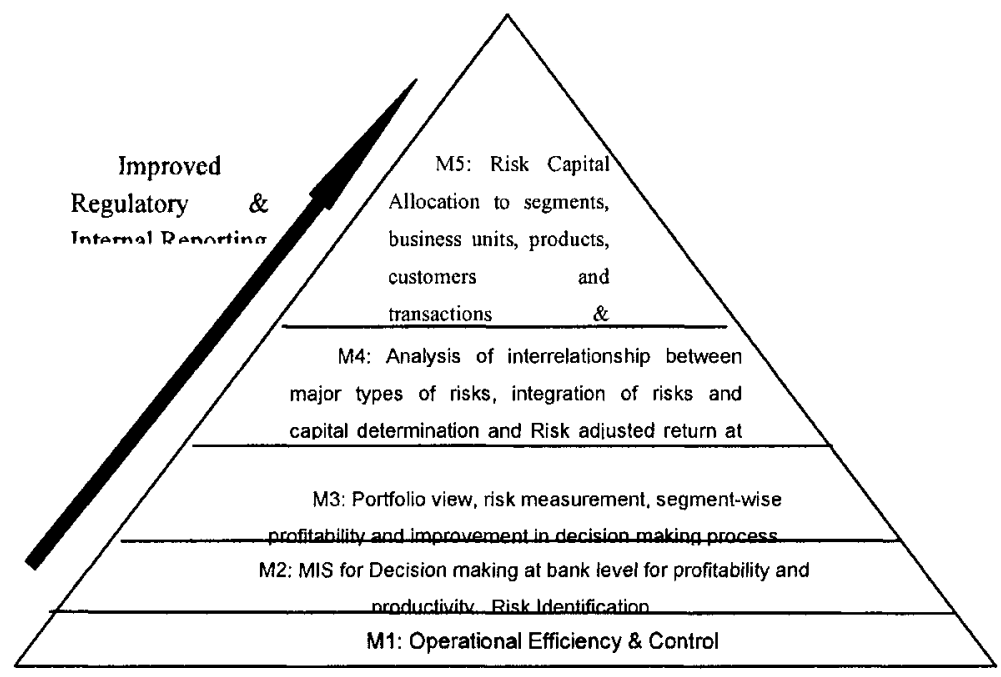

Fig. 2. EMM Business objectives

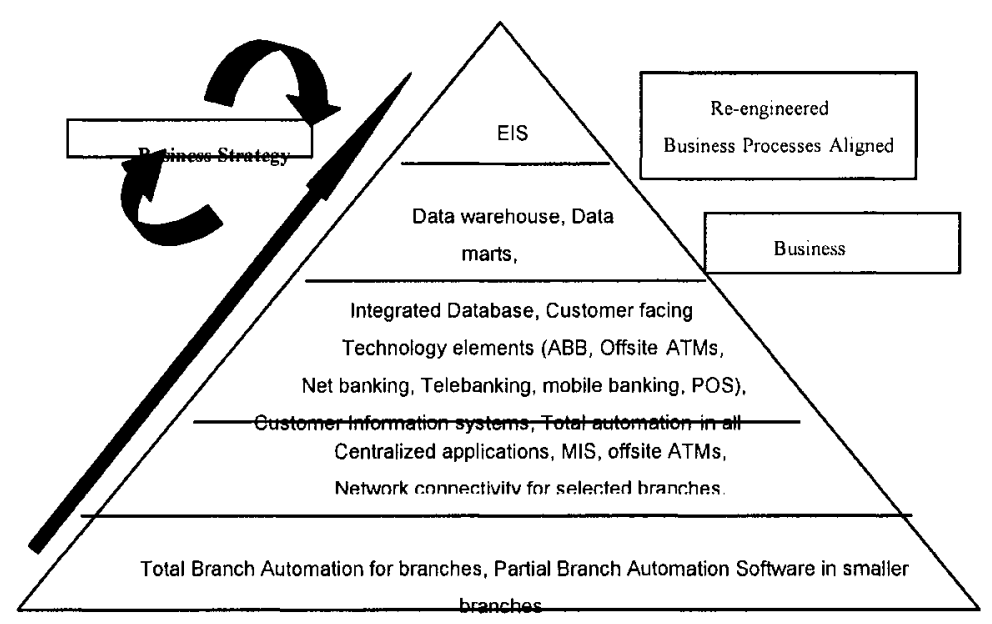

Fig. 3. EMM Technology Model 


\section{Conclusions}

In this paper a new Enterprise level Maturity Model, which can be implemented in layers is proposed. The approach used in this paper is very unique in contrast to existing methodologies such as strategic alignment model discussed in [9-11]. The proposed model facilitates banks to assess the layer in which its enterprise level information systems are and formulate a strategy to evolve their information systems in a multifaceted manner. As the implementation of the EMM reaches completion, banks would also have an intelligent EIS to make the best business decisions. Further extensions to the model are underway to take care of control aspects recommended by Basel II [12].

\section{References}

1. H. Diwakar and A. Saha, Integration of IT Strategy with Business strategy for Banks, NIBM, Project Report, 2003.

2. Banking Technology Handbook, edited by Jessica Keyes (CRC Press, 1999).

3. Reserve Bank of India, Guidance Note Asset-Liability Management (1999).

4. J.F. Sinkey, Commercial Bank Financial Management in the Financial Service Industry (Prentice Hall, New Jersey, 2002).

5. A. Saunders and L. Allen, Credit Risk Measurement (John Wiley \& Sons, West Sussex, 2002).

6. J. Bessis, Risk Management in Banking (John Wiley \& Sons Ltd., West Sussex, 2003)

7. A. Saunders and M.M. Cornet, Financial Institute Management: A Risk Management Approach, (McGraw Hill, 2003).

8. F.J. Fabozzi, The Handbook of Fixed Income Securities (McGraw- Hill, New York, 1997).

9. J.C. Henderson and N. Venkatraman, Strategic Alignment: Leveraging Information Technology for Transforming Organizations, IBM Syslems Journal 32(1), 4-16 (1993).

10. R. Sabherwal, R. Hirschheim, and T. Goles in: Strategic Information Management: Challenges and Strategies in Managing Information Systems, edited by R.D. GAlliers and D.E. Leidner (Elsevier -Butterworth-Heinemann, Oxford, 2004), pp 311-346.

11. N. Luftman, P.R. Lewis, S.H. Oldach, Transforming the Enterprise: The Alignment of Business And Information Technology Strategies, IBM Systems Journal 32(1) 198-221 (1993).

12. Basel II, (Nov 2005): http://www.bis.org 